\title{
Prikazi
}

https://doi.org/10.22210/suvlin.2018.086.09

\section{Ivana Filipović Petrović (2018): Kada se sretnu leksikografija i frazeologija. O statusu frazema u rječniku. Zagreb: Srednja Europa, 230 str.}

Znanstvena monografija Kada se sretnu leksikografija i frazeologija. O statusu frazema u rječniku objavljena je u lipnju 2018. godine u izdavačkoj kući Srednja Europa. Dr. sc. Ivana Filipović Petrović znanstvena je suradnica u Zavodu za lingvistička istraživanja Hrvatske akademije znanosti i umjetnosti. Dvije su u naslovu spomenute znanstvene discipline, leksikografija i frazeologija, područja autoričina znanstvenoga zanimanja i bavljenja više od jednoga desetljeća. Njima je autorica zaokupljena i u svojoj doktorskoj disertaciji naslovljenoj Status frazema u Benešićevu »Rječniku hrvatskoga književnoga jezika od preporoda do I. G. Kovačića", obranjenoj 2014. godine na Filozofskome fakultetu u Zagrebu. Ova je znanstvena monografija nastala na temelju spomenute doktorske disertacije, no prva je cjelina gotovo potpuno nova u odnosu na disertaciju, kao i polovica treće, kako sama autorica ističe u Predgovoru. Monografija koju predstavljamo obuhvaća sljedeća poglavlja i dijelove: Uvod, Leksikografija: između znanosti i zanata, Frazeologija: stazama lingvističke discipline, Kada se sretnu leksikografija i frazeologija, Zaključak, Izvori i rječnici, Bibliografija, Popis slika, grafikona itablica i Indeks frazema.

S obzirom na teorijsko uporište i perspektivu iz koje Ivana Filipović Petrović promatra i analizira frazeme i njihovu obradu u leksikografskim djelima monografija će razveseliti ne samo leksikografe i frazeologe nego isto tako i kognitivce jer je kognitivna znanost podloga na kojoj autorica gradi svoj istraživački rad u ovome tekstu. Kognitivna je znanost za autoricu "pista« s koje »uzlijeće« frazeološko tumačenje analizirane jezične građe.

Napomenuli bismo da se aktualnost odabrane teme iz područja leksikografije i frazeologije ne iščitava nužno iz samoga naslova monografije, no zato je već iz Uvoda jasno da je riječ o studiji koja predstavlja lakunu u frazeologiji i frazeografiji u nas. U redcima koji slijede to ćemo i potkrijepiti te pokazati da autorica na 230 stranica pažljivo "gradi« svoj tekst: najprije mu minuciozno udara teorijske temelje, odnosno sveobuhvatno ga teorijski podlaže - i u području leksikografije i u području frazeologije - a potom na tim temeljima postavlja "građevnu konstrukciju«, odnosno analizu i tumačenje prikupljene frazeološke građe, da bi na kraju »krovnu konstrukciju « teksta činila praktična rješenja koja autorica nudi, tj. arhitektura frazemskih rječničkih članaka u elektroničkoj frazeografiji koja na hrvatskoj leksikografskoj sceni ne postoji.

U Uvodu (str. 1-4) se najavljuju poglavlja monografije, ali i središnje pitanje knjige koje bismo saželi na sljedeći način: kako leksikografski obraditi frazeme koji 
se u suvremenim frazeološkim istraživanjima više ne tretiraju kao okamenjene, nepromjenjive jezične jedinice nego kao jedinice koje imaju varijante i koje su podložne modifikacijama, a da ta leksikografska obrada počiva na uporabnom modelu jezika, odnosno da se temelji na korpusnim istraživanjima?

Nakon uvodnog dijela slijedi prva cjelina (str. 5-40) od ukupno tri cjeline sadržane u knjizi, a naslovljena je Leksikografija: između znanosti i zanata. To je zapravo drugo poglavlje knjige. Autorica ga dijeli na tri potpoglavlja, a svako od njih još na nekoliko manjih. U prvom se potpoglavlju naslovljenom Od najstarijih lista riječi do e-leksikografije (str. 5-21), kako sam naslov sugerira, donosi najprije povijesni pregled razvoja leksikografije od leksikografskih početaka u Kini, preko leksikografskih djela u starom Rimu pa sve do hrvatske leksikografije od 15./16. st. naovamo. Potom se govori o srednjovjekovnim glosarima, odnosno pretečama današnjih rječnika, zatim o prijelomnom trenutku u povijesti razvoja leksikografije, tj. o revoluciji u tipografiji krajem 15 . st. te o tome kako se to odrazilo na rječnike i njihovu makrostrukturu i mikrostrukturu. Posebnu pozornost autorica skreće na književne citate u rječniku, odnosno na ulogu koju su imali (i još uvijek dobrim dijelom imaju) primjeri upotrebe riječi u djelima poznatih pisaca. Budući da je autorica u svojoj doktorskoj disertaciji analizirala leksikografski rad i prinos Julija Benešića, razumljivo je da u ovoj knjizi u povijesnom dijelu razvoja leksikografije posebno mjesto zauzima upravo njegov Rječnik hrvatskoga književnoga jezika od preporoda do I. G. Kovačića, a svoje su mjesto u knjizi našle i slike rukopisnih kartica iz tog Rječnika (str. 14-15). Pregled povijesti razvoja leksikografije autorica završava tumačenjem važnosti koju je imao drugi prijelomni trenutak, odnosno računalna obrada teksta, za razvoj leksikografije. Riječ je o eri elektroničke leksikografije vezanoj za korpusna istraživanja pa tako autorica, naslanjajući se na riječi Rosamund Moon, navodi da je u posljednjih tridesetak godina zadatak leksikografije prerastao iz opisa idealnog jezika u idealizirani opis jezika u upotrebi (str. 16). Poseban je naglasak stavljen na pregled razvoja računalne obrade jezika u nas te na hrvatsku e-leksikografiju. Autorica zaključuje kako se u nas rječnici sporadično temelje na izboru primjera iz korpusa, no ističe kako nema korpusno vođenog (engl. corpus driven) rječnika (str. 18). U drugom se potpoglavlju autorica pita Postoji li teorija leksikografije (str. 22-33). Odgovore nudi pregledom različitih i zapravo suprotstavljenih stajališta poznatih imena engleske, francuske i danske leksikografije o tom pitanju. U ovom se dijelu spominje Rezolucija Euralexa iz 2016. godine čiji je cilj priznavanje statusa leksikografije kao zasebne znanstvene discipline. Autorica završava taj dio navodom podatka o uključenosti leksikografije u UNESCO-ovu klasifikaciju znanosti i tehnologije. Nadalje se autorica u istom potpoglavlju pita Što je rječnik: uloga i namjena. Zanimljiv pokušaj autoričina odgovora na postavljeno pitanje jest konzultiranje rječnika samoga. Ivana Filipović Petrović zaključuje kako je stav o rječniku kao knjizi s neospornim autoritetom zapravo posljedica preskriptivističke tradicije koja je rječniku namijenila dvojaku svrhu: poučavanje i standardizaciju (str. 26), a uloga bi suvremenog rječnika zapravo trebala biti opis jezika koji vjerno odgovara 
jezičnim podatcima iz reprezentativnoga nacionalnog korpusa (str. 27). Objašnjenjem sheme engleskih leksikografa Sue Atkins i Michaela Rundella na str. 29 autorica odgovara na još jedno pitanje iz podnaslova: Što mora znati leksikograf: tehniku ili teoriju. Autorica se posvećuje i aspektu vezanom za korisničke potrebe i očekivanja (Što žele korisnici: naći ono što traže) poentirajući kako su te potrebe i očekivanja korisnika važan dio stvaranja rječnika. Svrha je primjera upotrebe u rječniku neosporna. O tome Što je dobar primjer upotrebe autorica također zasebno piše u ovom poglavlju te zaključuje, baš kao i Atkins i Rundell, kako primjeri trebaju biti tipični, informativni i shvatljivi. O sudaru dvaju titana, kako ih autorica naziva, odnosno o Leksikografiji i lingvistici, raspravlja se u zadnjem potpoglavlju prve cjeline (str. 3443). Posljednjih šezdesetak godina, otkada je leksikon postao predmet zanimanja i bavljenja lingvista, odnosno otkada raste zanimanje za semantiku, mijenja se i stav prema leksikografiji. Kako se leksikografi nose s problemom broja značenja riječi, autorica ilustrira u dijelu naslovljenom »Ne vjerujem u postojanje značenja riječiı, što je citat Sue Atkins iz 1994. Autorica pledira za dekontekstualizaciju i generalizaciju u rječnicima. U zadnjem dijelu prve cjeline pod naslovom Ipak: oblikovanje riječi govori se o umjetnosti objašnjenja. U konačnici se zaključuje da se ne mogu sve riječi u rječniku jednako objasniti (str. 39) te kako objašnjenja trebaju biti prilagođena potrebama korisnika.

Frazeologija: stazama lingvističke discipline naziv je trećega poglavlja (str. 4181), odnosno druge cjeline u radu i ono se, baš kao i prethodna cjelina, može promatrati kao zaseban rad, i to u didaktičke svrhe. Ivana Filipović Petrović i ovu cjelinu razbija na tri potpoglavlja, a potpoglavlja na još manje dijelove, no svi su oni logično i pomno isprepleteni, kao što je to bio slučaj i u prvoj cjelini. U prvom se potpoglavlju, Kamo je dosad stigla (str. 41-43), sažeto govori o povijesti frazeologije, kao što je to (u različitim opsezima) i uobičajeno u monografijama o frazeološkim temama, te se najavljuju, po autoričinu shvaćanju, dvije frazeološke škole, tj. tradicionalna i kognitivna, kojima se autorica podrobnije bavi u narednim dijelovima knjige. U drugom potpoglavlju, naslovljenom U ruhu formalnih pristupa jeziku (str. 44-57), autorica kreće od pitanja odnosa jezika i mišljenja u grčkih filozofa preko nezaobilaznog za tu temu Wilhelma von Humboldta pa do Ferdinanda de Saussurea i strukturalizma. Svoje su mjesto u ovom dijelu našli i Antoine Meillet, Roman Jakobson, Leonard Bloomfield i Noam Chomsky. Kao reakcija na chomskyjanski pristup proučavanju jezika pojavile su se studije o semantici J. J. Katza i J. A. Fodorova, o kojima autorica također piše. Osim pregleda povijesti frazeoloških istraživanja frazeolozi u svojim knjigama redovito donose i razgranat spektar termina koji su u uporabi u toj lingvističkoj disciplini te se pozicioniraju u tom smislu. Stoga u dijelu pod naslovom Frazeološka terminologija autorica navodi termine većinom iz anglojezične prakse. Na ovom mjestu valja istaknuti i termin koji sama autorica odabire i rabi u svojoj knjizi za jezičnu jedinicu kojom se bavi, a to je višerječnica. Njome se naslanja na engleski termin multi-word lexical unit koji služi kao svojevrsni hiperonim frazemu prema prijedlogu Branke Tafre (str. 46). Ruska frazeološka škola i odjeci u Europi 
naslov je idućeg dijela drugog potpoglavlja i u njemu se govori o počecima frazeologije vezanima za ruske jezikoslovce V. V. Vinogradova, N. M. Šanskog, S. I. Ožegova i A. I. Molotkova. Posebnu pozornost autorica poklanja ruskom sljedbeniku transformacijsko-generativne gramatike Igoru Mel'čuku i njegovoj podjeli višerječnih sveza. Na kraju se ovog dijela spominje V. N. Telija kao glavna predstavnica ruske struje koja se bavi istraživanjem kulturnih podataka iskazanih u frazemima, a dijelom se ta struja oslanja na spoznaje kognitivne lingvistike. Riječje o lingvokulturološkom pravcu u frazeologiji koji autorica izrijekom u knjizi spominje tek na str. 75. Idući kratki dio nosi naslov Kategorizacija frazema, a služi kao prijelaz u dio o kognitivnoj školi u frazeologiji: Frazeološka tradicija u Americi i psiholingvistička istraživanja. Autorica navodi kako je tradicionalni pogled na frazeme u američkoj frazeologiji umnogome bio određen transformacijsko-generativnim teorijskim okvirom. Na takvo shvaćanje reagira J. J. Katz. Nadalje se spominju B. Fraser, U. Weinreich, W. Chafe te se donose njihova shvaćanja frazema. Nastavlja se na to i pregled nekoliko psiholingvističkih istraživanja koja su se provodila u svrhu procesa doslovnog ili figurativnog razumijevanja frazema. U tom smislu autorica objašnjava i okvire konfiguracijske hipoteze C. Cacciari i P. Tabossi iz 1988. Sljedeći dio (Razvoj hrvatske frazeologije i zagrebačka frazeološka škola) posvećen je pregledu razvoja frazeologije u Hrvatskoj od njezinih početaka, tj. od 70-ih godina prošlog stoljeća i frazeološkog rada Antice Menac i Josipa Matešića. Ovdje valja istaknuti ono što u knjizi nije jasno razgraničeno, a to je da Josip Matešić nije predstavnik zagrebačke frazeološke škole, iako dvoje istaknutih hrvatskih jezikoslovaca svoje frazeološke i frazeografske vrhunce jesu imali otprilike u istom razdoblju. Nakon toga Ivana Filipović Petrović bavi se temom Opseg frazema i stupnjevi desemantizacije te donosi shvaćanja Antice Menac i Željke Fink Arsovski vezana za granice frazeologije i definiranje frazema. U sljedećem se dijelu (Aspekti klasifikacije frazema) govori o frazeološkim istraživanjima proizašlima iz načela zagrebačke frazeološke škole, tj. o strukturnoj, sintaktičkoj i semantičkoj analizi. Zaključno: obilježja frazema prema tradicionalnoj frazeološkoj školi - dio je koji, kao što se najavljuje u naslovu, sažima sve kriterije za opis frazema u tradicionalnom pristupu frazeološkoj problematici, a to su: polileksičnost, nepromjenjivost (okamenjenost), reproduciranje u gotovom obliku, desemantiziranost i ustaljenost (konvencionaliziranost). U zadnjem potpoglavlju ove cjeline naslovljenom U smjeru kognitivne teorije (str. 58-81) središnje mjesto zauzima ideja o promijenjenom pogledu na jezik, odnosno ideja o iskustvenom realizmu kao temelju kognitivnolingvističke teorije. Objašnjava se najprije teorija konceptualne metafore, tj. dvodomenski model G. Lakoffa i M. Johnsona, potom i višeprostorni model teorije konceptualne integracije G. Fauconniera i M. Turnera. Autorica donosi i osnovne postavke uporabno utemeljene kognitivne gramatike R. Langackera. Kognitivna gramatika dokida razdvajanje leksikona i sintakse i stvara kontinuum simboličkih jedinica. Prvi dio trećeg potpoglavlja jest Preispitivanje tradicionalnoga modela: semantička raščlanjivost frazema, u kojem autorica opisuje razvoj kriterija za opis frazema u kognitivnom pristupu frazeološkoj analizi 
proizašlom iz funkcionalnih pristupa jeziku. Autorica napominje kako je kognitivni pristup proučavanju frazema proizašao iz potrebe "prevladavanja« jaza i pokušaja pronalaska problema u tumačenju jezičnog značenja razdvojenog od čovjekova konceptualnog sustava i enciklopedijskog znanja govornika određene jezične zajednice (str. 61). Ovdje se još objašnjava i dekompozicijska teorija autora R. Gibbs i N. Nayak, a potom i podjela i pristup proučavanju frazema koji upotrebljavaju Ch. Fillmore, P. Kay i M. O’Connor. Konstrukcija kao rješenje za prikaz frazema jest dio u kojem autorica predstavlja prednosti konstrukcijske gramatike A. Crusea i W. Crofta pred tradicionalnom gramatikom jer razvoj konstrukcijske gramatike predstavlja pomak od razdvajanja komponenata prema njihovoj interakciji, a to se u knjizi i donosi u obliku shematskih prikaza (str. 65). Nakon toga slijede dijelovi knjige pod naslovom Procesi razumijevanja frazema i Motivacija - proces u pozadini frazeoloških sveza. U potonjem se dijelu diskutira o temi interpretacije frazema gdje se autorica između ostaloga naslanja i na interpretaciju frazema Marije Omazić (str. 69). U dijelu pod naslovom Vrste semantičkih proširenja u pozadini frazema pobliže se analiziraju metafore i metonimije u motivaciji frazema pa se tako za metaforu navodi primjer to spill the beans, a za metonimiju primjer to have a shallow brain temeljen na metonimijama DIO ZA CJELINU, GLAVA ZA ČOVJEKA, GLAVA ZA MENTALNE SPOSOBNOSTI. Osim mehanizama metafore i metonimije za opis našeg konceptualnog sustava važni su i Kulturni modeli i konceptualna integracija, što je i naslov sljedećeg dijela knjige. Frazem vukujanjećoj koži takoje poslužio kao ilustracija konceptualne integracije, a frazemi baciti pijesak (prašinu) u oči komu, biti slijep kod zdravih očiju i imati mrenu na očima kao primjeri motivacije kulturnim modelom GLEDANJA. Sažimajući sve rečeno u ovom potpoglavlju, Ivana Filipović Petrović završava dijelom pod naslovom Aspekti transparentnosti frazema gdje se, naslanjajući se na A. Langlotza, donosi pregled mogućeg opisa transparentnosti frazema uz autoričine primjere ekscerpirane iz Benešićeva Rječnika. Dio nazvan Varijante i modifikacije frazema posvećen je središnjem pitanju u monografiji. Donosi se definicija konvencionalnih ili sustavnih varijanti, a isto tako i nekonvencionalnih varijanti ili kreativnih frazemskih motivacija (str. 75). Nabrajaju se koraci (ukupno njih pet) za razlaganje procesa u kojem se značenje sastavnica upotrebljava na određen način kako bi se došlo do značenja modifikacije. Treće potpoglavlje završava dijelom Frazeologija kao jezik kulture, u kojem autorica spominje i one frazeologe koji za tumačenje ukupnoga frazeološkog fonda nekogjezika nisu nužno objeručke prihvatili čisto kognitivnolingvističku perspektivu. Među njima su D. Dobrovol'skij i E. Piirainen. Na kraju se tog dijela usputno spominje lingvokulturologija, suvremena disciplina koja se razvija u Rusiji, a koja zapravo predstavlja »otapanje« u pomalo hladnoratovskoj podjeli tradicionalnog i kognitivnolingvističkog pristupa u frazeološkim istraživanjima. Zaključno: obilježja frazema prema kognitivnoj frazeološkoj školi - dio je koji, kao što se najavljuje u naslovu, sažima sve kriterije za opis frazema u kognitivnolingvističkom pristupu frazeološkoj problematici, a to su: polileksičnost, promjenji- 
vost (varijante i modifikacije), semantička transparentnost, konvencionalnost i reproduciranje u cjelovitom obliku.

U četvrtom poglavlju (str. 83-202) događa se susret najavljen u samom naslovu, a valja reći i da ovo poglavlje nosi isti naziv kao i monografija (Kada se sretnu leksikografija i frazeologija) jer to zapravo i jest - da se poslužimo pojmom dramske kompozicije - vrhunac ili kulminacija ove monografije. Ova, takoreći, treća cjelina obuhvaća dva potpoglavlja: Teorijski spoj: što želi leksikografija, a što frazeologija (str. 83-94) i Praktični spoj: status frazema u rječniku (str. 95-149) s prilogom (Prilog: Benešićeve varijantne fraze poslije Benešića) (str. 149-202). Na početku prvog potpoglavlja Teorijski spoj: što želi leksikografija, a što frazeologija autorica ističe da su frazemi izazov u izradi rječnika te citira Sue Atkins i kaže da su oni »močvara za leksikografe« (str. 83). Prva i najveća ograničenja postavlja određenje tipa rječnika, definiranje njegove namjene i opsega. Autorica napominje kako je važno da natuknički lik odražava najveću frekvenciju upotrebe frazema te da odgovara njegovoj sinkronijskoj upotrebi, a s obzirom na to da korpusi nude podatke o varijantama i modifikacijama frazema, posao je leksikografa odlučiti, tj. odabrati primjere za predstavljanje (str. 83). U sljedećim dijelovima prvoga potpoglavlja autorica podrobnije piše o pojedinim etapama leksikografske obrade frazema. U dijelu Obuhvatnost rječnika: granice frazema Ivana Filipović Petrovićjasno apostrofira da je odluka leksikografa ključna prilikom rješavanja pitanja o uključivanju frazema u rječnik i da se u tom poslu najbolje odražavaju stavovi leksikografa o granicama frazema. Status nadnatuknice i natuknički lik važan je zbog pretraživosti frazema pa je tako najbolje rješenje predvidljiv i dosljedan princip, smatra autorica. Morfološko načelo, zastupljeno u hrvatskoj frazeografskoj praksi, nije sasvim predvidljivo pa je tako za upotrebu rječnika nužno potreban i indeks frazema koji pomaže korisnicima u snalaženju. Osim toga, autorica pledira za srazmjer između natukničkog lika u rječniku i stvarne upotrebe koju pokazuje računalni korpus. Kada piše o Promjenjivim frazemima, autorica kao dobar primjer navodi engleski frazeološki rječnik Longman Idioms Dictionary iz 1998. jer se u njemu zasebno donose i modifikacije. U nas takvih primjera nema jer nemamo rječnike koji bi bili vođeni korpusom, a zanimljivo je da je Benešić uključivao modifikacije u svoj Rječnik. Primjeri upotrebe frazema važan su dio rječničke natuknice, a autorica smatra kako se »u suvremenoj hrvatskoj leksikografiji [...] premalo važnosti daje primjerima upotrebe, a u frazeografiji primjerima stvarne upotrebe« (str. 91). Što se, pak, tiče Oznake registra i drugih dodatnih informacija, hrvatski frazeološki rječnici rijetko sadržavaju bilo kakve odrednice. I ovdje se navodi isti dobar primjer iz engleske frazeografije s uputama o tome u kojim se situacijama frazem najčešće upotrebljava i tko ga upotrebljava. Drugo potpoglavlje u trećoj cjelini naslovljeno je Praktični spoj: status frazema u rječniku i u njemu se donosi pregled rezultata susreta leksikografije i frazeologije u nas. Kreće se od najstarijih rječnika (dio Prvi frazeografski prinosi u hrvatskim rječnicima), a iz već ranije u tekstu navedenog razloga posebno se pod lupu uzima Benešićev Rječnik. Slijedi Benešićeva frazeologija koja obuhvaća dijelove Fraze u Benešićevu Rječniku: rezultati 
analize, Fraze u Benešićevu Rječniku: primjeri iz analize i dio Benešićeva uloga u razvoju frazeološke misli. Ivana Filipović Petrović na temelju provedene analize i rezultata određuje J. Benešića kao preteču razvoja frazeološke misli s obzirom na to da je stvarao u doba prije negoli se frazeologija osamostalila kao lingvistička disciplina i u začecima hrvatske moderne leksikografije, a njegov pristup autorica određuje i kao blizak kognitivnom pristupu. U dijelu Novi svesci u doba suvremene leksikografije govori se oleksikografskom radu pod uredničkom palicom Anje Nikolić-Hoytiz Zavoda za lingvistička istraživanja Hrvatske akademije znanosti i umjetnosti gdje se dovršava Benešićev Rječnik. Nadalje, u dijelu O dosadašnjim hrvatskim frazeološkim rječnicima autorica se usredotočuje na analizu dvaju naših rječnika: Frazeološkog rječnika hrvatskoga ili srpskoga jezika (1982) J. Matešića i Hrvatskog frazeološkog rječnika (2014) autorskog trojca A. Menac, Ž. Fink Arsovski i R. Venturin. Zapravo posljednji dio u monografiji prije priloga (Prilog: Benešićeve varijantne fraze poslije Benešića) jest dio naslovljen Mrežni frazeološki rječnik hrvatskoga jezika vođen korpusom i on je temelj i plan za izradu frazeološkog e-rječnika na kojem autorica Ivana Filipović Petrović radi zajedno s Jelenom Parizoskom. U narednim se dijelovima potom govori o odabiru korpusa kojim će rječnik biti vođen (Temelji: odabir korpusa), o načinu prikupljanja frazeološke građe (Prikupljanje frazema), te se na kraju donose primjeri natuknica iz planiranog rječnika kao ilustracije svega opisanoga (Primjeri leksikografske obrade frazema). Autorice također planiraju dodati konceptualni ustroj rječnika, o čemu se više govori u dijelu Abecedno-konceptualna organizacija. U dijelu Prilog: Benešićeve varijantne fraze poslije Benešića (str. 149-202) donosi se tablica s prikazom statusa skupine frazema u četirima hrvatskim rječnicima (Benešićevu Rječniku, dvama već spomenutim frazeološkim rječnicima hrvatskog jezika iz 1982. i 2014. i u Velikome rječniku hrvatskogajezika V. Anića iz 2003.).

U Zaključku (str. 203-204) se podsjeća na središnje pitanje postavljeno u Uvodu i na odgovor koji se "postupno nudi « u trima cjelinama knjige.

Znanstvena monografija završava pregledom Izvora i rječnika te iscrpnim popisom korištenih izvora (Bibliografija), koji zainteresiranom čitatelju mogu poslužiti za daljnja samostalna istraživanja i/ili produbljivanja teme; Popisom slika, grafikona itablica i Indeksom frazema.

Zaključno valja istaknuti da je riječ o iznimno vrijednom doprinosu hrvatskoj leksikografiji i hrvatskoj frazeologiji, i to na teorijskoj, metodološkoj, analitičkoj i interpretativnoj razini. Knjiga može poslužiti svim jezikoslovcima koji se bave navedenim disciplinama kao uzor s obzirom na znanstvenu argumentiranost i vjerodostojnost. Ona će zasigurno biti korisna svim filolozima u nas - od studenata preddiplomskih, diplomskih i poslijediplomskih studija pa sve do nastavnika i znanstvenika, a autoričino e-frazeografsko djelo s nestrpljenjem iščekujemo s obzirom na to da na tom mjestu na hrvatskoj frazeografskoj sceni postoji praznina.

Branka Barčot 